Adelia Carstens

Adelia Carstens is verbonde aan die Eenheid vir Akademiese Geletterdheid, Universiteit van Pretoria. E-pos: adelia.carstens@up.ac.za

\section{Geletterdheidsnarratiewe as spieël van die motiveringsrolle van betekenisvolle andere}

\section{Literacy self-narratives as mirror for the motivation roles of significant others}

During recent years the reading and writing of literacy self-narratives has received renewed attention in Higher Education. Of particular interest are the ways in which these narratives reflect the literacy identities that students construe for themselves and significant others, and how this knowledge may assist lecturers of academic literacy in curriculum reform. This contribution reports on research that was aimed at exploring the roles that Afrikaans mother-tongue first-year BEd students construe for significant others in terms of their support or suppression of literacy development. The New Literacies served as a theoretical vantage point for the pedagogy of the module in question, whereas a model combining insights from the New Literacies and Self-determination Theory was used to analyse 15 narratives qualitatively. A main finding is that the students demonstrate a strong need to feel competent at performing literacy activities, and that teachers are the primary sponsors of such feelings. Parents and other primary caregivers are the second most salient category of significant others who contribute feelings of competence. Parents' influence start in early childhood, when they initiate early literacy acitivies with their children. These activities create feelings of relatedness, leading to the development of feelings of mastery in the children, and then later in the school career culminate in autonomous literacy-acquisition behaviours. The article is concluded by suggestions to lecturers on how to enhance students' feelings of competence through classroom interaction and classroom activities. Keywords: learner motivation, literacy narratives, significant others, sponsor identities.

\section{Inleiding}

Gedurende die afgelope twintig jaar geniet die lees en skryf van geletterdheidsnarratiewe deur universiteitstudente in taalmodules op universiteitsvlak toenemend aandag. Akademiese publikasies oor geletterdheidsnarratiewe fokus veral op hulle potensiaal om kurrikulumverandering teweeg te bring deurdat geletterdheidsnarratiewe ruimte skep om na studente se stemme te luisterenersyds om vas te stel hoe hulle hul eie geletterdheidsidentiteit ervaar, en andersyds hoe hulle die identiteite konstrueer van individue en instansies wat hulle geletterdheidswording bevorder of gestuit het. Vir dosente kan studente se selfnarratiewe lig werp op hulle leerders se oortuigings en aannames oor die aanleer van ' $n$ bepaalde tipe geletterdheid (Williams; Clark en Medina); hulle insig gee in studente se weerstand teen bepaalde pedagogiese oogmerke; en hulle 
OORGANGE EN VOORTGANGE: 'n Huldigingsbundel vir C. H. F. Ohlhoff

ondersteun in die ontwikkeling van' $n$ meer dialogiese benadering tot kurrikulumontwikkeling en -hervorming (Ball; Clark en Medina; Corkery; Soliday).

Terenzini e.a en Wroots het studente se oorgang van hoërskool na universiteit bestudeer deur studente se geletterdheidsnarratiewe te ontleed. Mendelowitz bespreek drie selfnarratiewe as gevallestudies. Haar bevindinge herbeklemtoon die moontlikhede wat die selfnarratief open om te besin oor die sosiale implikasies van geletterdheidsverhale. Dit is ook die oorkoepelende tema van die werk van Busch, Jardine en Tjoutuku. In die inleiding onderskryf Busch die feit dat die biografiese benadering nie primêr belang stel in die uniekheid van ' $n$ bepaalde lewensverhaal nie, maar eerder in die sosiale dimensies van die taalpraktyke wat help om dit te eksternaliseer. Williams se artikel oor die identiteite wat studente vir hulleself en hulle onderwysers in hulle narratiewe skep, bied 'n tentatiewe klassifikasie van' $n$ aantal prototipiese identiteite wat na vore gekom het in ander navorsers se werk, maar min inligting word gegee oor die navorsingsmetodes wat in hierdie studies gebruik is. Opsommend kan gesê word dat nie een van die bovermelde studies sistematiese getuienis aanbied oor hoe studente hulle eie identiteite of dié van ander rigtinggewers in hulle geletterdheidsgeskiedenis voorstel nie. Geen konkrete voorstelle word ook gemaak oor hoe sodanige inligting in taal- en geletterdheidskurrikulums en as deel van klaskamerpraktyk benut kan word nie. Hierbenewens fokus al die bogenoemde studies op Engels, en die stryd van die tweedetaal- en vreemdetaalspreker van Engels om aan te pas in kontekste waar Engels die voertaal is (byvoorbeeld skole en universiteite) en waar die kultuur van die akademie as vreemd en bedreigend ervaar word. Min of geen navorsing is tot op datum gedoen oor hoe Afrikaanssprekendes hulle geletterdheidsidentiteit ervaar en watter rol belangrike ander persone hierin speel nie.

Die navorsingsprojek waaroor hierdie bydrae verslag doen, is gestuur deur die vraag: Hoe kan studente se geletterdheidsnarratiewe dosente help om studentgesentreerde kurrikulums vir Akademiese Geletterdheid in die BEd-program te ontwerp? Ten einde hierdie vraag te beantwoord, is twee meer konkrete subvrae gevra:

- Watter multigeletterdheidsidentiteite konstrueer studente vir hulleself in hulle geletterdheidsnarratiewe?

- Watter ondersteunende (of nie-ondersteunende) identiteite konstrueer studente vir betekenisvolle andere in hulle geletterdheidsnarratiewe?

Die fokus van hierdie bydrae val op die beantwoording van laasgenoemde vraag.

156 Teoretiese vertrekpunte vir die pedagogiek van geletterdheidsnarratiewe Binne die raamwerk van die Nuwe Geletterdhede, Multigeletterdhede en Multimodaliteit kan geletterdheid gedefinieer word as die vermoë om konvensionele 
tekensisteme te gebruik vir betekenisskepping-sowel om sin te maak uit bestaande tekste as om idees so te verpak dat ander dit kan interpreteer (New London Group; Newfield en Maungedzo; Kress).

Tradisioneel verwys die term geletterdheidselfnarratief na outobiografiese verhale wat handel oor taalverwerwing en formele onderrig. (Eldred en Mortensen 513; Coffey 11). In kanonieke voorbeelde van hierdie genre is die verteller gewoonlik 'n persoon wat as' $n$ minderbevoorregte in'n gemarginaliseerde groep grootgeword het, en wat teenslae oorkom het deur byvoorbeeld die grense van taalwêrelde suksesvol te deurbreek, universiteitsopleiding te ondergaan, ' $n$ sukses te maak van sy/haar professie, en dan skryf uit'n posisie van bevoorregting. Kanonieke voorbeelde uit die VSA is Richard Rodrigues se Hunger of Memory (1982) en Victor Villenueva se Bootstraps: From an American Academic of Color (1993). Suid-Afrikaanse voorbeelde sluit in: Emmanuel Mgqwashu se 'On becoming literate in English: a during- and post-apartheid personal story'; Aziza Jardine se 'Ampe Proudly Kaaps-a language biography from the Western Cape'; en Angelika Tjoutuku se 'Treating the colonial language fever. A Namibian language biography' (Mgqwashu; Busch, Jardine en Tjoutuku 71-99).

Al die bogenoemde publikasies het'n overte politieke agenda, wat die identiteit en intensionaliteit van die outeur beklemtoon en sosio-konstruktiwisties kyk na betekenisgewing. Die fokus val egter op betekenisgewing slegs deur middel van die geskrewe woord. Geen aandag word geskenk aan die konsep 'multigeletterdhede', wat die aandag vestig op die veelvoud van kommunikasiekanale wat in hedendaagse kommunikasie gebruik word nie. Die beskouing van multigeletterdhede daag die outonome beskouing van geletterdheid uit, en gee erkenning aan die diverse maniere waarop mense betekenis skep in sowel die tradisionele as die nuwe media, en in sowel openbare, private, gemeenskaps- as ekonomiese domeine (Stein en Newfield). Devereux en Wilson vestig die aandag daarop dat mense vandag' $n$ hele repertorium van geletterdheidspraktyke beoefen, wat toepaslik in verskillende kontekste gebruik word. Die realiteit van'n verskeidenheid uitdrukkingsmedia het aanleiding gegee tot die ontstaan van die teoretiese rigting wat bekend staan as Multimodaliteit. Multimodaliteit is'n benadering wat belang stel in die gebruik van'n verskeidenheid semiotiese stelsels-soos byvoorbeeld teks, visuele voorstelling, klank, uitbeelding in driedimensionele ruimte, beweging, ensovoorts—om betekenis te skep in sowel tradisionele as nuwe media (Kress en Van Leeuwen).

Op basis van Barton en Hamilton het Carstens (“Using literacy narratives")'n raamwerk opgestel vir die ontleding en ontwerp van geletterdheidselfnarratiewe. Hierdie raamwerk maak voorsiening vir' $n$ verskeidenheid van uitdrukkingsmodusse en -media en verreken die volgende dimensies van geletterdheidsverhale: geletterdheidspraktyke, geletterdheidsdomeine, geletterdheidsaktiwiteite, hulpmiddels/hindernisse, en geletterdheidsfasiliteerders (Eng: sponsors). 
OORGANGE EN VOORTGANGE: 'n Huldigingsbundel vir C. H. F. Ohlhoff

Geletterdheidspraktyke is wat mense met geletterdheid doen. Volgens Barton en Hamilton word geletterdheidspraktyke gekenmerk deurdat:

- hulle struktuur bepaal word deur sosiale instellings en magsverhoudinge;

- sommige praktyke meer dominant, invloedryk en sigbaar is as ander;

- hulle ingebed is in breër sosiale doelwitte en kulturele praktyke;

- hulle oor tyd heen mag verander en nuwe praktyke aangeleer word deur prosesse van informele leer en verstaan van die werklikheid (Barton en Hamilton 7).

Geletterdheidsdomeine is lewensterreine, soos byvoorbeeld die huis, skool, werkplek, plekke van aanbidding, ens. Volgens Barton en Hamilton (11) is die huis'n primêre domein aangesien dit sentraal staan tot die ontwikkeling van sosiale identiteit. Verder word elke domein gekenmerk deur bepaalde diskoersgemeenskappe, waarvan die lede ' $n$ taalvariëteit, konvensionele handelinge en 'n stel waardes deel (Coffey 98). Geletterdheidsgebeurtenisse is aktiwiteite waarin geletterdheid'n rol speel (Barton en Hamilton 8). In'n universiteitsomgewing is geletterdheidspraktyke die aktiwiteite waaraan studente herhaaldelik deelneem, soos die skryf van opstelle of eksamens (Coffey 79).

Geletterdheidsfasiliteerders (sponsors) is sleutelfigure in die narratief, wat deur Brandt gedefinieer word as "any agents, local or distant, concrete or abstract, who enable, support, teach, and model, as well as recruit, regulate, suppress, or withhold, literacy" (Brandt 19). Hamilton verkies die inklusiewe term deelnemers (participants) in plaas van sponsors, aangesien dit ook die verteller as 'n gespreksdeelnemer insluit. 'Deelnemer' kan weer verbind word aan Williams se identiteite (identities), wat spesifiek verwys na die beelde wat studente van hulleself en ander gespreksdeelnemers, onder andere onderwysers, konstrueer. Volgens Williams (844) sluit die waardes wat studente vir hulle dosente konstrueer die volgende in: held, martelaar, versorger en swaap (buffoon). Williams bied egter nie empiriese getuienis aan oor die frekwensie en kontekste van voorkoms nie. Met verwysing na fotonarratiewe identifiseer Hamilton (28) bykomend artefakte (artefacts), oftewel voorwerpe wat gedurende geletterdheidsverwerwing'n instrumentele rol vervul. Artefakte sluit gewoonlik tekste in (wat gelees of geskryf word), maar kan in'n multigeletterdheidskonteks waarskynlik ook musiekinstrumente, kunsmateriaal, rekenaars, ensovoorts, insluit.

\section{Analise van geletterdheidsnarratiewe Data-insamelingsprosedure}

158 As deel van die standaardkurrikulum van'n akademiesegeletterdheidsmodule wat geïntegreer is met' $n$ kernmodule word daar van BEd-studente verwag om twee weergawes van hulle outobiografiese narratiewe te produseer:'n multimodale 
narratief, waarin ten minste twee uitdrukkingsmediums gebruik word (bv. teks en foto's), gevolg deur'n monomodale geskrewe essay wat van dieselfde inhoud gebruik maak. Gedurende die beplanningsfase word Barton en Hamilton se raamwerk in die klas bespreek. Studente moet ook self navorsing doen deur byvoorbeeld onderhoude te voer met familielede en onderwysers; en stawende dokumentasie, soos foto's van geletterdheidshulpmiddele en geletterdheidsfasiliteerders, te neem of te vind. Daarna moet elke student'n tydlyn opstel waarop die belangrikste geletterdheidsgebeurtenisse in sy/haar geletterdheidsgeskiedenis aangedui word. Bo- en onderkant die tydlyn word aanduidings gegee van die geletterdheidsfasiliteerders en geletterdheidshulpmiddele wat met die gebeurtenis verbind word. Studente word daarop bedag gemaak dat geletterdheidsnarratiewe nie bloot' $n$ chronologiese weergawe van gebeure is nie, maar dat dit veral belangrik is om te besin oor die impak van die gebeure op hulle persoonlike identiteit.

As deel van die kurrikulum stel studente eers' $n$ multimodale geletterdheidsnarratief saam, en bespreek hulle narratiewe dan in die klas in groepsverband. Die oogmerk is om studente insig te laat verwerf in die diversiteit van leerders wat hulle in skoolklaskamers kan verwag. Die taal- en etniese homogeniteit van die Afrikaansmedium- akademiesegeletterdheidsklasse aan die Universiteit het egter tot gevolg dat studente nie die diversiteit van geletterdheidsagtergronde ervaar wat ooreenstem met die demografie van die Suid-Afrikaanse of selfs die regionale bevolking nie, en dus nie insig verwerf in die diversiteit van leerders wat hulle in skoolklaskamers mag teëkom nie. Desnieteenstaande is dit dosente se ervaring dat die onderlinge bespreking van individuele geletterdheidsnarratiewe Afrikaanssprekende studente wel help om hulle eie geletterdheidsgeskiedenis in perspektief te plaas, en krities oor die waarde van gebeure, fasiliteerders en ander hulpbronne in hulle lewens te besin.

Om studente vir die skryf van die monomodale geletterdheidsnarratief voor te berei, bespreek die dosent die tipiese struktuur van'n narratiewe essay, beginnende by'n doelstelling of hipotese, gevolg deur die chronologiese uiteensetting wat volgens' $n$ duidelike plan geparagrafeer is, en afgesluit word deur' $n$ slotbeskouing waarin krities besin word oor die waarde wat die student daaruit put om sy/haar geletterdheidsgeskiedenis te dokumenteer.

In 2012 is etiese klaring verkry vir 'n omvattende navorsingsprojek oor geletterdheidsnarratiewe. In daardie jaar is 57 essays wat in Engels geskryf is, geanaliseer. Carstens en Alston en Carstens ("Lens”) rapporteer volledig oor die bevindinge van hierdie navorsing.

In 2013 is die navorsing in Afrikaansmedium-lesinggroepe gerepliseer. Honderd-en-dertig studente is deur hulle klasdosent versoek om naas die papierkopieë van hulle geletterdheidsnarratiewe wat vir assessering ingedien is, ook'n elektroniese kopie aan die dosent te stuur. Ten spyte daarvan dat almal inge- 
OORGANGE EN VOORTGANGE: 'n Huldigingsbundel vir C. H. F. Ohlhoff

ligtetoestemmingsbriewe onderteken het, het slegs 15 studente egter aan die versoek voldoen om hulle narratiewe vir navorsing beskikbaar te stel. Daar kan bloot gespekuleer word dat die swak respons hoofsaaklik daaraan toe te skryf is dat die studente geen rendement gesien het op die addisionele moeite om hulle narratiewe ná assessering elektronies in te dien nie.

Hoewel die steekproef klein is (ongeveer $12 \%$ van die totale getal studente wat ingeligte toestemming verleen het), is daar egter tog neigings in die data waargeneem, wat hieronder bespreek sal word.

\section{Analise van fasiliteerder-identiteite}

Die analiseproses

Die 15 opstelle is ontleed deur gebruik te maak van die kwalitatiewe data-analiseprogram AtlasTi, weergawe 7. Dit is nie nodig geag om addisionele kodeerders te gebruik vir die versekering van interkodeerderbetroubaarheid nie, aangesien die betroubaarheid van die outeur se kodering bevestig is tydens die ontleding van die 57 soortgelyke geletterdheidsnarratiewe in Engels, waaroor gerapporteer word in Carstens en Alston en Carstens ("Lens"). Die volgende stel van 14 kodes ter benoeming van fasiliteerder-identiteite het induktief na vore gekom gedurende die ontleding van die Engelse data, en het as invoer gedien vir die ontleding van die Afrikaanse tekste: hero, role model, enhancer, liberator, effective facilitator, motivator, pastor, advisor, peer supporter, trigger, witness, bully, suppressor, bureaucrat en absent authority (Alston en Carstens, "Lens"). Die Afrikaanse data het'n veel beperkter stel kodes opgelewer, naamlik rolmodel, effektiewe fasiliteerder, motiveerder, pastor, sneller, bullebak, burokraat en oneffektiewe fasiliteerder. Die definisies vir elkeen van hierdie kodes word in Tabel 1 hier onder gegee:

\begin{tabular}{ll} 
Kode & Definisie \\
\hline Rolmodel & lemand waarna ander opsien as 'n navolgenswaardige voorbeeld. \\
\hline Effektiewe fasiliteerder & $\begin{array}{l}\text { lemand wat ander suksesvol onderrig, veral op grond van 'n bepaalde } \\
\text { vaardigheid, opleiding, kennis of ervaring. }\end{array}$ \\
\hline Motiveerder & $\begin{array}{l}\text { lemand wat 'n ander se belangstelling in of entoesiasme vir 'n aktiwiteit } \\
\text { aanwakker deur vertroue in sy/haar vermoëns te stel, goedkeuring aan } \\
\text { sy/haar handelinge te verleen en sy/haar prestasie te beloon. }\end{array}$ \\
\hline Pastor & lemand wat emosioneel of psigologies vir ander omgee en dit prakties uitleef. \\
\hline Sneller & $\begin{array}{l}\text { lemand wat 'n ander aanmoedig en stimuleer om 'n bepaalde vaardigheid } \\
\text { te begin verwerf. }\end{array}$ \\
\hline Bullebak & $\begin{array}{l}\text { lemand wat krag of mag gebruik om ander handelinge onder dwang te laat } \\
\text { uitvoer of hulle te intimideer. }\end{array}$ \\
\hline
\end{tabular}


GELETTERDHEIDSNARRATIEWE as spieël van die motiveringsrolle van betekenisvolle andere

\begin{tabular}{ll} 
Kode & Definisie \\
\hline Burokraat & $\begin{array}{l}\text { lemand wat vereis dat ander volgens die letter van die wet optree, en wat } \\
\text { struktuur bo openheid verkies. }\end{array}$ \\
\hline Oneffektiewe fasiliteerder & $\begin{array}{l}\text { lemand wat nie daarin slaag om ander suksesvol te onderrig nie, onder andere } \\
\text { as gevolg van 'n gebrek aan vaardigheid, kennis en opleiding; of as gevolg van } \\
\text { 'n negatiewe ingesteldheid teenoor die ander persoon. }\end{array}$ \\
\hline
\end{tabular}

Tabel 1: Definisies van kodes vir identiteitsrolle wat deur betekenisvolle andere vertolk word

'n Tweede kodefamilie, bestaande uit 13 kodes, wat die belangrikste betekenisvolle andere benoem, het uit die Engelse tekste na vore gekom, te wete: mother, father, parents, brother, sister, grandmother, grandfather, uncle, aunt, caretaker, friend, peer, en therapist. Weer eens het die Afrikaanse data' $n$ beperkter stel kodes opgelewer as die Engels, te wete ma, pa, ouers, broer, suster, ouma, oupa, oppasser en terapeut. Dit is interessant dat tannie en oom, asook vriend en portuurgroeplid, glad nie figureer nie. Die Afrikaanse data het wel'n bykomende kode opgelewer, naamlik praktykgemeenskap — een van die sosiale groepe waarvan die opstelskrywer' $n$ lid is, en wat'n betekenisvolle rol gespeel het in sy/haar verwerwing van' $n$ bepaalde geletterdheidspraktyk, byvoorbeeld'n kerk- of gemeentegroep, debatvereniging, ensovoorts.

'n Derde kodefamilie, bestaande uit die kodes bevoegdheid, verbintenis en outonomie, is gebruik om die rolle te benoem wat geletterdheidsfasiliteerders speel om leerders te motiveer op hulle geletterdheidsreis. Die drie kodes is afkomstig uit Selfbeskikkingsteorie, 'n kognitief-sielkundige teorie wat verklarings bied vir motivering en prestasie binne die konteks van onderrig en leer. Oënskynlik is dit teenstrydig om ' $n$ individualistiese psigologiese teorie te gebruik vir die interpretasie van sosiale konstrukte soos die identiteite van geletterdheidsfasiliteerders-ook gegewe die pedagogiese raamwerk van multigeletterdheid en multimodaliteit waarin die kurrikulum en die pedagogiek van die module ingebed is. In plaas van Selfbeskikkingsteorie sou daar gesteun kon word op teorieë wat tweedetaalmotivering vanuit' $n$ sosiaalsielkundige perspektief ondersoek (Gardner; Dörnyei en Csizér; Cheng en Dörnyei). Sodanige teorieë fokus egter op taalaanleer as sodanig, en nie op die verwerwing van multigeletterdheid binne en buite die klaskamer nie. Verder is Selfbeskikkingsteorie meer onlangs wel toegepas in domeine waarbinne die rol van situasionele en kontekstuele faktore in die ontwikkeling van geletterdheid beklemtoon word (Anderman en Anderman; Borg en Al-Busaidi; Ryan en Stiller; Ryan, Stiller, en Lynch; Urdan en Turner). Vervolgens word 'n oorsig gegee oor die relevansie van Selfbeskikkingsteorie om fasiliteerder-identiteite binne'n opvoedkundige konteks beter te verstaan. 


\section{Selfbeskikkingsteorie}

Volgens Selfbeskikkingsteorie is motivering een van die belangrikste bepalers van suksesvolle en onsuksesvolle studie. Mense is veral suksesvol in hulle verwerwing van nuwe kennis en vaardighede indien hulle intrinsiek geïnteresseerd is in die objek van studie. Veral dan is nuwe aktiwiteite genotvol, word geassimileer wat geleer is, en word die nuwe kennis suksesvol toegepas (Ryan en Deci). Dit lei weer tot verhoogde prestasie, deursettingsvermoë en algemene welstand.' $n$ Voorwaarde is egter dat die betrokke aktiwiteit intrinsiek interessant moet wees, dit wil sê nuut,' $n$ uitdaging en/of esteties bevredigend.

Anderman en Anderman, Borg en Al-Busaidi, Ryan en Stiller, Ryan, Stiller en Lynch, en Urdan en Turner het bevind dat effektiewe leer en prestasie bevorder kan word deur betekenisvolle ander persone. Hoewel intrinsieke motivering die effektiefste dryfveer is in'n leerder se geletterdheidsontwikkeling, kan bepaalde vorme van ekstrinsieke motivering ook leerder-aksie en leerder-agentatitwiteit bevorder. Ryan en Deci beklemtoon die feit dat die ekstrinsieke doelwit by sekere tipes motivering deur die individu self bekragtig word, en dus met' $n$ mate van wilskrag aanvaar word (Ryan en Deci 55). Indien 'n ouer, onderwyser of ander betekenisvolle persoon weet hoe om vorme van ekstrinsieke motivering te gebruik wat tot vrywillige handeling by die leerder lei, eerder as om kontrole te probeer uitoefen, kan hoëkwaliteitleer wel plaasvind. Geletterdheidsfasiliteerders moet dus ervare wees om intrinsieke motivering te ontgin en om studente aan te spoor om ekstrinsieke doelwitte te internaliseer, sodat hulle die waarde daarvan in die onderrig- en leersituasie kan besef. Opvoedkundige aktiwiteite is egter dikwels nie intrinsiek interessant nie, en daarom moet die ouer, onderwyser of ander fasiliteerder die leerder motiveer om ekstrinsieke beweegredes te internaliseer vir die uitvoer van noodsaaklike, maar minder aangename, take. Op hierdie manier kan bepaalde waardes en vrywillige handelinge deur die leerder geïntegreer word (Ryan en Deci 60; Urdan en Turner 3).

Volgens Selfbeskikkingsteorie is die drie psigologiese behoeftes wat deur intrinsiek gemotiveerde handelinge bevredig word, maar wat ook deur betekenisvolle ander persone gekataliseer kan word, bevoegdheid, outonomie en verbintenis. Volgens Selfbeskikkingsteorie is die behoefte aan bevoegdheid' $n$ basiese psigologiese behoefte, en indien hierdie behoefte bevredig word, kan dit intrinsieke motivering vir die uitvoer van ' $n$ bepaalde taak of take stimuleer. Studente sal meer geneig wees om 'n eksterne doelwit te aanvaar en te internaliseer indien hulle dit verstaan en die vaardighede besit om dit suksesvol toe te pas (Ryan en Deci). In die sielkundeliteratuur word die term 'selfdoeltreffendheid' ('selfefficacy') dikwels gebruik om na persoonlik ervaarde bevoegdheid te verwys, oftewel studente se oortuiging dat hulle daartoe in staat is om spesifieke vaardighede te verwerf (Bandura; Pajares 546). Schunk gee'n aantal praktiese wenke oor hoe selfdoeltreffendheid deur onderwysers bevorder kan word, byvoorbeeld 
deur realistiese doelwitte te stel wat tog' $n$ mate van'n uitdaging bied deur studente te help om in hulle eie kognitiewe vaardighede te glo, byvoorbeeld deur positiewe terugvoer te gee indien leerders se werk daarvan getuig dat hulle die inhoud verstaan; deur voorbeelde vir modellering te gee; en deur aanprysings of belonings (Schunk; Ryan en Deci). Hierdie soort aktiwiteite is sosiaal en konstruktief, eerder as bloot individueel en kognitief, aangesien leer bevorder word deur interaksie tussen dosent/onderwyser en leerder, asook tussen leerders onderling. Urdan en Turner (7) en Ryan en Deci (59) maan onderwysers om nie terugvoer te gee wat leerders onbevoeg en minderwaardig laat voel nie. Nie alleen kan'n leerder se selfvertroue daardeur geskaad word nie, maar dit kan ook gevoelens van skaamte na vore bring as gevolg van die ervaring van openbare vernedering.

Verbintenis het te doen met' $n$ gevoel van emosionele nabyheid aan ander asook respektering deur betekenisvolle andere, soos byvoorbeeld ouers, onderwysers, portuurgroeplede en die gemeenskap. Ouers is primêre verbintenisfigure. Weens die geografiese en emosionele nabyheid tussen ouer en kind is hulle in staat om hulle kinders se selfpersepsie betekenisvol te beïnvloed gedurende die vroeë fases van ontwikkeling (Ryan, Stiller en Lynch 228). 'n Realistiese selfbeeld spruit onder andere uit die vraag-en-antwoordroetines wat kenmerkend is van vroeë interaksie met prenteboeke. Ouers en ander primêre versorgers (soos kinderoppassers en grootouers) is ook die primêre modelle vir die vorming van toekomstige verhoudings. Ryan en sy kollegas het ook' $n$ hoë korrelasie gevind tussen kinders se voorstellings van hulle ouers en dié van onderwysers in die voorspelling van skoolverwante uitkomste: Kinders wat'n gevoel van ondersteuning deur hulle ouers ervaar het, was meer geneig om sterk, gesonde verhoudings met hulle onderwysers te ervaar (Ryan, Stiller en Lynch 243-46). In aansluiting hierby het leerders se gevoelens van verbintenis teenoor onderwysers gelei tot sterker ervarings van beheer oor en beheersing van hulle omstandighede (Noddings; Wentzel). Hierdie bevindinge strook met onderwysers se persepsies oor die belangrikste motiveringstrategieë in die taalklaskamer. Uit'n studie deur Dörnyei en Csizér onder tweedetaalonderwysers in Hongarye het dit geblyk dat die skep van'n ondersteunende klimaat in die klaskamer die naasbelangrikste motiveringstrategie uit'n lys van tien items was, terwyl vreemdetaalonderwysers in China dit as die vierde belangrikste motiveringstrategie gelys het (Cheng en Dörnyei; Dörnyei en Csizér).

Die derde faktor in die stimulering van intrinsieke motivering binne die raamwerk van Selfbeskikkingsteorie is gevoelens van outonomie. Volgens hierdie teorie sal intrinsieke motivering slegs verhoog word indien gevoelens van bevoegdheid saamgaan met'n ervaring van outonomie, oftewel'n interne lokus van oorsaak en gevolg (Ryan en Deci 57). Dit is dus noodsaaklik dat die leerder in 'n mate self kan kies, asook geleenthede kry om self te bepaal hoe hy/sy bepaalde uitkomste wil bereik (Borg en Al-Busaidi). Stefanou, Perencevich, DiCintio en Turner het drie tipes gedrag gelys waardeur onderwysers leerder-outonomie kan 
bevorder: organisatories, prosedureel en kognitief. Organisatoriese outonomie het daarmee te doen dat studente toegelaat word om keuses te maak aangaande die klaskameromgewing, deur byvoorbeeld self groeplede te kan kies. Prosedurele outonomie kom na vore wanneer dosente aan studente beheer gee oor 'vorm', byvoorbeeld om materiaal en temas te kies vir klasprojekte, asook hoe bemeestering van' $n$ vaardigheid gedemonstreer kan word. Kognitiewe outonomie-ondersteuning behels dat geleenthede geskep word sodat leerders eienaarskap van leerervarings kan aanvaar, soos byvoorbeeld geleenthede om probleme self op te los en om verskillende oplossings vir'n spesifieke probleem te vind. Hierdie soort outonomie vind 'n mens hoofsaaklik op meer gevorderde vlakke in die natuurwetenskappe en ingenieurswese, waar patente ontwerp kan word vir toestelle, prosesse en meganismes om probleme op te los of oplossings te optimeer. Volgens Ryan en Deci (57) sluit inhibeerders van outonomie onder andere in: dreigemente, keerdatums, opdragte en kompetisiedruk. Urdan en Turner (7) noem die volgende: inmenging met leerders se normale leertempo en inhibering van die uitspreek van kritiese en onafhanklike menings.

\section{Bespreking van bevindinge}

Die bevindinge van die navorsing word bespreek aan die hand van die identiteitsrolle wat betekenisvolle andere speel om gevoelens van bevoegdheid, outonomie en verbintenis by'n groep Afrikaanssprekende BEd-studente te bewerkstellig. Waar voorbeelde uit studente se narratiewe aangehaal word, word pseudonieme gebruik om na geletterdheidsfasiliteerders te verwys ten einde hulle anonimiteit te verseker.

\section{Bevoegdheid}

Bevoegdheid is die psigologiese behoefte wat die sterkste figureer in die Afrikaanse geletterdheidsnarratiewe. Hierdie kode is altesaam 67 keer toegeken. Onderwysers is die kategorie van betekenisvolle andere wat die prominentste figureer. Hulle tree veral op as effektiewe fasiliteerders (22 keer gekodeer), en ook in ' $n$ beperkte mate as motiveerders ( 3 keer gekodeer). ' $n$ Voorbeeld van die konstruksie van die onderwyser as' $\mathrm{n}$ effektiewe fasiliteerder word gevind in opstel 11:

En juffrou Inge Steiger, sy het altyd haar beste gegee en geglo in jou as leerder.

Ek WOU my beste vir haar ook doen en het altyd baie moeite in my take gedoen en met ' $n$ onderskeiding in matriek vir haar vak weggestap.

Slegs in twee gevalle word onderwysers gekonstrueer as persone wat afbreuk doen aan'n gevoel van bevoegdheid: een keer is die kode bullebak toegeken en in een geval die kode oneffektiewe fasiliteerder.

Primêre versorgers, naamlik ma, pa, ouers, ouma, oupa en oppasser, behaal gesamentlik die tweede hoogste telling vir bevoegdheid. Binne hierdie inklusie- 
we kategorie lewer $m a$ 's verreweg die grootste bydrae (byna twee keer soveel as onderwysers). Dit is interessant dat die primêre versorgers van Afrikaanssprekende studente' $n$ aansienlik groter bydrae lewer tot gevoelens van bevoegdheid as dié van studente wat Engels as voertaal kies. Dit kan moontlik daardeur verklaar word dat die vlak van skoling by ouers van universiteitstudente wat Afrikaans as onderrigmedium kies, oor die algemeen hoër is as by dié wat Engels kies, en dat die Afrikaanssprekendes as kinders in die reël by ouers, eerder as by lede van die uitgebreide familie, grootgeword het. In die geval van Afrikaans-moedertaalsprekers kan ouers (veral ma's) dus in'n groter mate optree as verlengstukke van die skool deur met huiswerk te help en hulle kinders aan te moedig om aan ander geletterdheidsaktiwiteite (ook buitemuurs) deel te neem. Hierdie ouers kan ook gewoonlik makliker as kinders uit Afrikataalsprekende gemeenskappe opvoedkundige hulpmiddele, instrumente en toestelle (artefakte) bekostig om hulle kinders se geletterdhede te help bevorder, waardeur gevoelens van bemeestering kan ontstaan en groei.

Dit is verder insiggewend dat praktykgemeenskappe in twee gevalle binne dieselfde essay geskets word as effektiewe fasiliteerders wat gevoelens van bevoegdheid na vore laat kom, byvoorbeeld opstel 10:

Ek het my hele hoërskool loopbaan elke tweede naweek by 'n koffiewinkel op 'n christelike kamp gewerk. Daar het ek geletterd geraak in finansies, die ekonomiese mark en ook die Bybel. Ons kon 'n paar lesings bywoon elke kamp. Ek het so baie geleer by daardie kamp en ek kan dit elke dag gebruik. Ek het ook geleer hoe om met mense te werk en ook van die besigheidswêreld. [...] Ek het met redenaars en Toastmasters voortgegaan in die hoërskool. [...] Ek dink redenaars het my gehelp om my woordeskat in Engels en Afrikaans te verbreed en dit het defnitief [sic] my vermoë om sinskonstruksie te struktureer aangehelp.

'n Grafiese opsomming van die bevindinge ten opsigte van bevoegdheid word in Figuur 1 gegee.

\section{Verbintenis}

Verbintenis is altesaam 46 keer gekodeer. Figuur 2 toon aan dat' $n$ verskeidenheid van betekenisvolle ander persone bydraes gelewer het tot gevoelens van verbintenis by die studente waarvan die geletterdheidsnarratiewe ontleed is.

Weereens lewer primêre versorgers die grootste bydraes: $m a$ (15), pa (3), ouers (8), ouma (2) en oupa (1). Die dominante fasiliteerderrolle is effektiewe fasiliteerder, sneller en motiveerder.

Ouers figureer sterk in terme van die rol wat hulle speel om kinders geborge te laat voel in'n geletterdheidskonteks. Dit is interessant dat $m a^{\prime} s$ 'n meer prominente rol as onderwysers speel in die rol van effektiewe fasiliteerder. Dit dui daarop dat 
OORGANGE EN VOORTGANGE: 'n Huldigingsbundel vir C. H. F. Ohlhoff

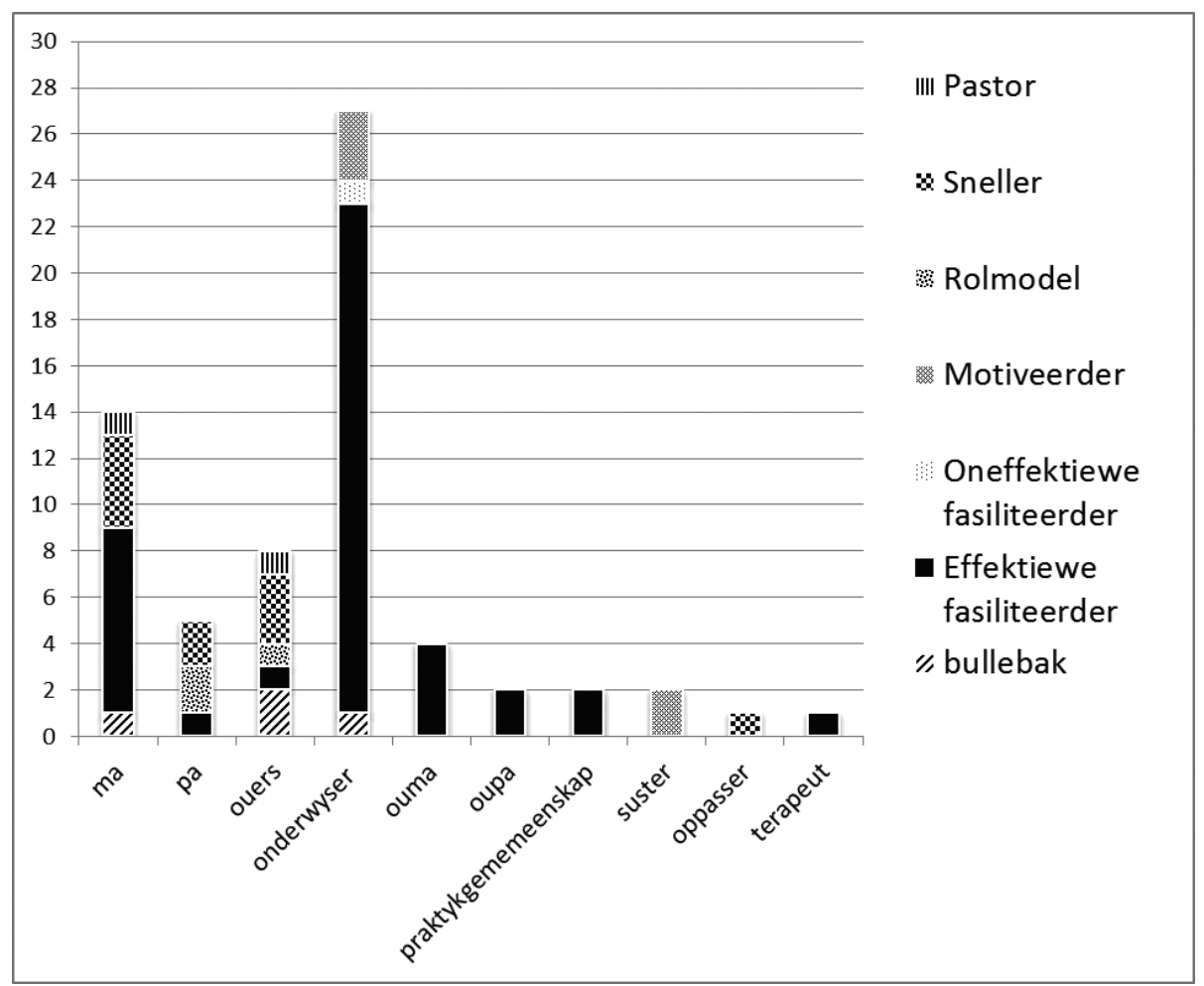

Figuur 1: Verbande tussen studente se gevoelens van bevoegdheid en die rolle waarin betekenisvolle andere gekonstrueer word.

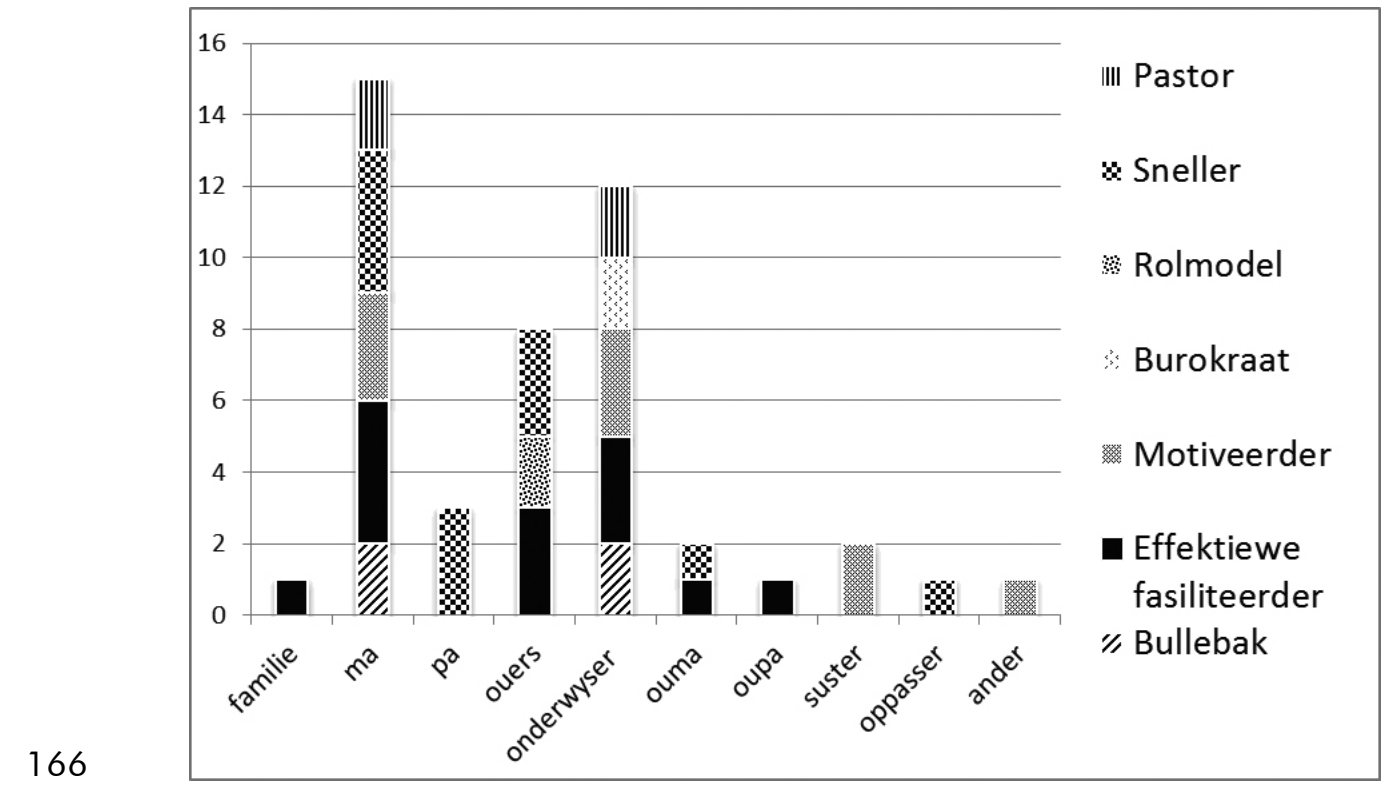

Figuur 2: Verbande tussen studente se gevoelens van verbintenis en die rolle waarin betekenisvolle andere gekonstrueer word 
kinders se ervaring van'n ouer wat tyd saam met hulle spandeer, en hulle sodoende bemagtig om ' $n$ bepaalde tipe geletterdheid te verwerf, ervaar word as'n ouer wat omgee. Hierdie investering van gehaltetyd kan gevoelens van verbintenis verder verdiep. Die bevinding dat geletterdheidsneller die tweede meeste koderings uitgelok het en die sterkste verbind word aan primêre sorggewers (veral $m a$, pa en beide ouers) is te verwagte, aangesien ouers en hulle plaasvervangers tipies daardie persone is wat leerders aan geletterdheidsaktiwiteite blootstel, soos om deur prenteboeke te blaai en vrae te beantwoord, saam rekenaarspeletjies of kaartspeletjies te speel, saam musiek te maak, ensovoorts. Die skrywer van narratief 12 vertel hoe sy ma hom geleer het om kaart te speel, en hoe dit sy syfergeletterdheid bevorder het:

My duidelikste herinnering van my eerste geletterheidservaring [sic] was toe my moeder my geleer het om met kaarte te speel. Ek was nog 'n voorskoolse geletterde en my moeder het minstens elke dag by die huis my geleer om met kaarte te speel. Met die kaarte was ek elke dag blootgestel aan syfers en my moeder het my gestimuleer om die kaarte se syfers te vergelyk en basiese somme te kan maak in orde om te kan "wen." Dus, het ek só my eerste omvatting [sic] van Wiskunde gekry.

Anders as in die Engelse opstelkorpus word $p a^{\prime} s$ —-naas $m a^{\prime}$ 's en onderwysers-in die Afrikaanse korpus prominent gekonstrueer as geletterdheidsnellers, soos vervat in die volgende aanhaling:

Ek kan wel onthou dat my pa elke aand vir my kom boek lees het in my bed.

Hy het vir my 'n rympie of ' $n$ versie, of net 'n lekker storie gelees, uit ' $n$ groot wit boek. Die manier waarop hy dit vertel het, die verskillende stemtone, die geluide wat hy nageboots het. Dit is een ding wat my altyd sal bybly. (Opstel 5)

Hierdie sosialiseringsaktiwiteite gaan dan dikwels oor in meer gerigte pogings om die kind te onderdompel in geletterdheidsaktiwiteite soos lees skryf, teken, musiek maak, rekenaargeletterd raak, ensovoorts. Daarenteen blyk dit uit die Engelse korpus dat $p a$ 's in tradisionele landelike gemeenskappe baie selde as snellers betrokke is; moontlik omdat hulle dikwels ver van die huis en die gesin werk.

\section{Outonomie}

Vergelykbaar met die Engelse korpus is outonomie die minste kere gekodeer in vergelyking met bevoegdheid en verbintenis. Altesaam is slegs 13 kodes toegeken. Anders as in die Engelse korpus, waar onderwysers die hoofbydraers tot positiewe gevoelens van outonomie is, word $m a^{\prime}$ s en $p a^{\prime}$ s in die Afrikaanse korpus gekonstrueer as die betekenisvolle ander persone wat die grootste bydrae lewer om hul kinders keuses te gee, asook die vryheid om te eksperimenteer en berekende risiko's te neem. Figuur 3 som die bevindinge rondom outonomie op. 


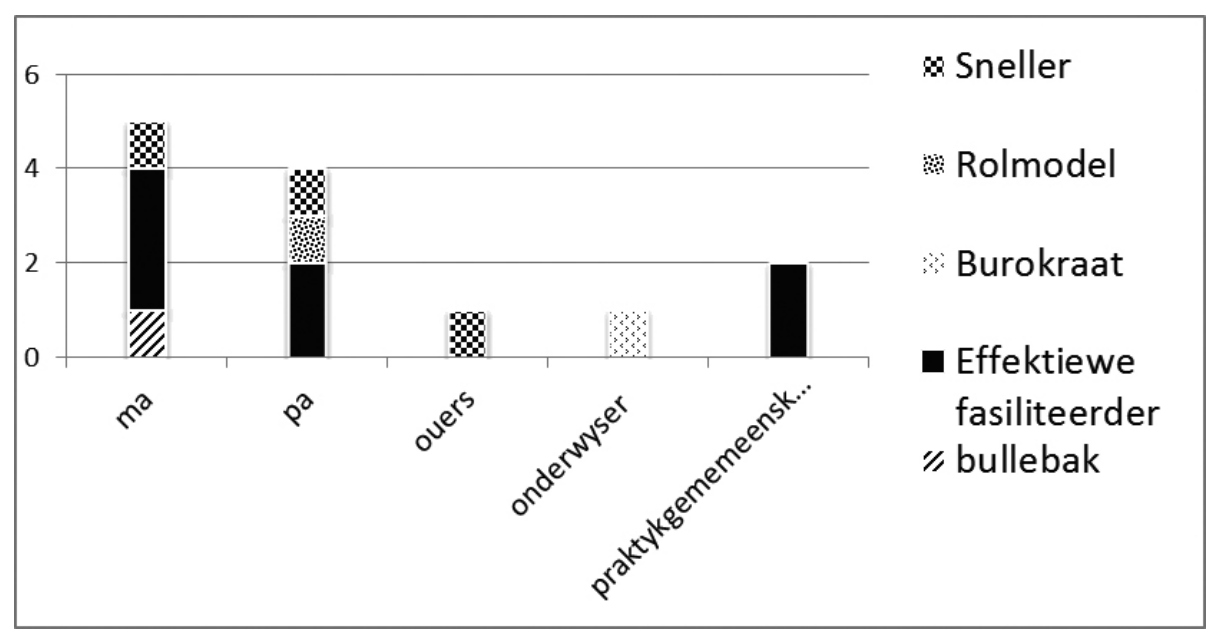

Figuur 3: Verbande tussen studente se gevoelens van outonomie en die rolle waarin betekenisvolle andere gekonstrueer word

Anders as in die Engelse korpus, waar bevryder (liberator) en adviseur (advisor) die rolle is wat die meeste toegeken is (aan onderwysers), word die rol van effektiewe fasiliteerder in die Afrikaanse korpus die meeste kere aan $p a^{\prime}$ s en $m a^{\prime}$ s toegeken waar dit gelei het tot gevoelens van outonomie by die kinders (nou studente). Opstel 11 weerspieël'n konstruksie van die positiewe invloed wat ouers kan hê deur leer aktief te fasiliteer, en dan terug te staan sodat die kind op eie houtjie kan probeer. Op hierdie manier word gevoelens van outonomie opgewek, wat dikwels weer gevoelens van eiewaarde voed:

My pa het ook ons altyd by gestaan [sic] waar ons hulp nodig gehad het, en natuurlik gehelp met al die take. Hy sou dit nooit vir ons doen of bou nie, ons moes by staan [sic] en kyk en help, daai tyd was dit nie vir my te oulik nie want almal se ouers doen mos dit vir hulle, maar as ek nou terug kyk het ek groot wardeuring [sic] daar voor [sic] want dit het my geleer om selfstandig te wees, self te kan dink en ek het baie meer daar uit geleer. In graad 9 moes ek selfs soldeer en sweis vir'n ekspo taak! En ons was afdeling wenners op die ou einde.

\section{Samevatting en gevolgtrekking}

Anders as in die Engelse korpus, waaruit dit blyk dat leerders se grootste psigologiese behoefte dié is om te voel dat ander mense vir hulle omgee, vertoon die Afrikaanssprekende leerders' $n$ sterker behoefte aan bevoegdheid; oftewel, hulle konstrueer die behoefte aan bemeestering as een van die sterkste dryfvere in hulle geletterdheidsontwikkeling. Die behoefte aan bevoegdheid is dus by hulle klaarblyklik een van die sterkste voorspellers van intrinsieke motivering om aan 
geletterdheidspraktyke deel te neem. ' $n$ Ander verklaring vir die groter prominensie van bevoegdheid is moontlik geleë in die manier waarop die koderingsisteem sekere "rame" rondom inligting plaas. Die kodeerder het dit byvoorbeeld moeilik gevind om eenduidig te bepaal watter rol(le) ouers speel in die vroegste interaksies (met hulle kinders) waarby tekste (verbaal en visueel) betrokke is. Hoewel hierdie interaksies waarskynlik aanvanklik eerder gevoelens van verbintenis as bevoegdheid uitlok, gaan hierdie gevoelens dikwels byna outomaties oor in gevoelens van bemeestering en bevoegdheid. Dit gebeur toenemend soos wat meer komplekse response van die kind verwag word, en soos wat daar aan hom/ haar groter outonomie en groter beheer gegee word. Hierdie verklaring resoneer met Pomeranz, Grolnick en Price se beskrywing van ouerbetrokkenheid (parent involvement). Volgens hulle manifesteer ouerbetrokkenheid in aktiwiteite soos saamlees met kinders, maar ook belangstelling toon in hulle lewens deur skoolaktiwiteite by te woon en deur saam met kinders opgewonde te wees oor hulle suksesse (Pomerantz, Grolnick en Price 261). Hierdie aktiwiteite dra by tot gevoelens van bevoegdheid en' $n$ versterking van gevoelens van verbintenis tussen ouers en kinders. Volgens navorsing wat deur Anderman en Anderman aangehaal word, het adolessente wat hulle ouers as betrokke, struktuurgewend en ondersteunend ervaar het (dit wil sê as outoriteitsfigure) ook vertroue in hulle eie bevoegdheid gerapporteer.

Vir die onderrig van akademiese geletterdheid is hierdie bevindinge betekenisvol deurdat dit die belangrikheid daarvan beklemtoon om studente bevoeg te laat voel oor wat hulle ken, weet en kan doen. Die volgende literatuurgesteunde strategieë kan dus met vrug in klaskamerpraktyk en gedurende assessering geïnkorporeer word:

- Gee terugvoer wat sukses verbind met harde werk (Deci en Ryan 64; Anderman en Anderman).

- Deel belonings uit wat vir studente bewys lewer van hulle vordering. In' $n$ onlangse navorsingsprojek oor die rol van affektiewe faktore in studente se leesontwikkeling het Boakye (215) bevind dat swakker studente meer as sterker studente gebaat het by aanprysing en belonings. Aanprysings voor klasmaats laat studente nie net goed voel oor hulle eie vermoëns nie, maar versterk gevoelens dat die dosent hulle raaksien en dat hulle vir hom/haar belangrik is. Pianta wys daarop dat die verhoudings wat leerders met onderwysers op skool het veral belangrik is vir dié wat op risiko is om akademies te faal of die skool te verlaat. Dit is dus veral belangrik dat dosente goeie verhoudings opbou met studente wat as risikogevalle bevind is deur formele geletterdheidstoetsing of op grond van hulle prestasie in toetse en eksamens.

- Bestuur groepwerk effektief deur groeplede met verskillende geletterdheidsvaardighede in een groep te plaas. Indien'n groep byvoorbeeld saam 
OORGANGE EN VOORTGANGE: 'n Huldigingsbundel vir C. H. F. Ohlhoff

'n multimodale projek moet doen, sou dit sinvol wees om studente met tegnologiese kennis, studente met artistieke talent en studente met bogemiddelde taalvaardigheid in een groep te plaas. Dit moet egter afgewissel word met individuele werk, aangesien veral laerisikostudente dikwels verkies om op hulle eie te werk. Versterking van gevoelens van bemeestering by sommige studente moet dus nie die behoefte aan keuse by ander studente oorskadu nie.

- Konsentreer op die gebruik van taal in die klaskamer wat gerig is op leer, verbetering van kennis en vaardighede, die aankweek van positiewe emosies en konstruktiewe samewerking, soos aanbeveel deur Perry, Turner en Meyer. Zammit brei uit op die rol van diskoerse in die bevordering van geletterdheid, veral onder leerders van lae sosio-ekonomiese klasse- wat ook heel gepas is in kontekste waar'n groot persentasie van die leerders se akademiesegeletterdheidsvaardighede nie op peil is nie. Sy onderskei vyf verskillende tipes diskoerse:

Kennis: erkenning van die 'inhoud' wat elke leerder na die klaskamer bring; Vermoë: versekering aan studente dat geen geletterdheidservaring onwaardig is om vertel te word nie, sodat alle studente kan ervaar dat hulle tot sukses in staat is;

Kontrole: "deel" van die pedagogiese ruimte in die klaskamer deur die dosent en al die studente;

Plek: ervaring van gevoelens dat elke student hoort en behoort en eienaarskap het van die leerproses;

Stem: ontwikkeling van'n eie "stem" in'n veilige omgewing.

Hierdie diskoerse resoneer met die drie die basiese psigologiese behoeftes van die student, naamlik outonomie (kontrole en stem), bevoegdheid (kennis en vermoë) en verbintenis (plek).

In'n opvolgstudie sou aksienavorsing as navorsingsmetode gebruik kon word om insig te verwerf in die toepaslikheid en die sukses van die voorgestelde strategieë om BEd-studente se intrinsieke motivering vir die verwerwing van akademiese geletterdheid te bevorder.

\section{Erkenning}

Linette van der Merwe was die koördineerder van die Afrikaansmedium-akademiesegeletterdheidsmodule, asook die klasdosent vir die betrokke lesingggroep, en het die data goedgunstiglik ingesamel. 2010. 
Ball, Arnetha. F. "Preparing teachers for diversity: Lessons learned from the US and South Africa," in Worlds of Meaning: Vygotskyan Perspectives on Literacy Research. Reds. Carol D. Lee en Paul Smagorinsky. Cambridge, MA: Cambridge Press, 2000, 314-59.

Bandura, Albert. Self-efficacy: The Exercise of Control. New York, USA: W. H. Freeman, 1997.

Barton, David, en Mary Hamilton. "Literacy practices," in Situated Literacies: Reading and Writing in Context. Reds. David Barton, Mary Hamilton en Ros Ivanič. Londen, UK: Routledge, 2000. 7-15.

Boakye, Naomi. "A socio-affective approach to improving students' reading comprehension abilities." PhD diss., U Pretoria, 2012.

Borg, Simon, en Saleh Al-Busaidi. "Teachers' beliefs and practices regarding learner autonomy." ELT Journal Advance Access. 2011. <http://eltj.oxfordjournals.org>.

Brandt, Deborah. Literacy in American Lives. Cambridge: CUP, 2004.

Busch, Brigitta, Aziza Jardine, en Angelika Tjoutuku. Language Biographies for Multilingual Learning. PRAESA Occasional Papers 24. Cape Town, RSA: U Cape Town, 2009.

Carstens, Adelia. "Using literacy narratives to scaffold academic literacy in the Bachelor of Education: a pedagogical framework." SA Journal for Language Teaching 46.2 (2012): 9-25.

. "Through the lens of BEd students' self-narratives: The motivational roles of significant others in literacy acquisition." Education as Change. Journal of Curriculum Research, hangende. , en Linda-Anne Alston. "Literacy self-narratives as constructions of pre-service teachers' multiliterate and multilingual identities." Multilingual Teaching and Learning Innovations in Higher Education in South Africa. Reds. Christa van der Walt en Liesel Hibbert. Clevedon: Multilingual Matters, hangende.

Cheng, Hsing-Fu, en Zoltan Dörnyei. "The use of motivational strategies in language instruction: The case of EFL teaching in Taiwan," Innovation in Language Learning and Teaching 1.1 (1998): $153-74$.

Clark, Caroline, en Carmen Medina. "How reading and writing literacy narratives affect preservice teachers' understandings of literacy, pedagogy, and multiculturalism," Journal of Teacher Education 51.1 (2000): 63-76.

Coffey, Marjorie. Literacy Narratives across the Curriculum. MA thesis, Oregon State U, 2011.

Corkery, Caleb, "Literacy narratives and confidence building in the writing classroom." Journal of Basic Writing 24.1 (2005): 48-67.

Devereaux, L., en Kate Wilson. "Scaffolding literacies across the Bachelor of Education program: An argument for a course-wide approach." Asia-Pacific Journal of Teacher Education 36.2 (2008): 121-34.

Dörnyei, Zoltan, en Kata Csizér. “Ten commandments for motivating language learners: results of an empirical study." Language Teaching Research 2.3 (2007): 203-29.

Eldred, Janet C., en Peter Mortensen. “Reading literacy narratives." College English 54.5 (1992): 512-39.

Gardner, Robert C. Social Psychology and Second Language Learning: The Role of Attitudes and Motivation. Londen: Edward Arnold, 1985.

Hamilton, Mary."Expanding the New Literacy Studies: Using photographs to explore literacy as social practice." Situated Literacies: Reading and Writing in Context. Reds. David Barton, Mary Hamilton and Ros Ivanič. New York, NY: Routledge, 2000. 16-34.

Kress, Gunther. Multimodality. A Social Semiotic Approach to Contemporary Communication. Oxon: Routledge, 2010.

, en Theo van Leeuwen. Reading Images. The Grammar of Visual Design. Londen: Routledge, 1996.

Mendelowitz, Belinda. "Representing selves: Reflections on teaching memoir writing to preservice teachers." Perspectives in Education 23.1 (2005): 15-24.

Mgqwashu, Emmanuel. "On becoming literate in English: A during- and post-apartheid personal story." The Language Learning Journal 37.3 (2009): 293-303.

New London Group. "A pedagogy of multiliteracies: Designing social futures." Multiliteracies: Literacy Learning and the Design of Social Futures. Reds. Bill Cope en Mary Kalantzis. Melbourne: Macmillan, 2000. 9-37.

Newfield, Denise en Robert Maungedzo. "Mobilising and modalising poetry in a Soweto classroom." English Studies in Africa 49.1 (2006): 60-92.

Noddings, Nell, The Challenge to Care in Schools. Alternative Approaches to Education. New York: Teachers College Press, 1992.

Pajares, F. "Self-efficacy beliefs in academic settings." Review of Educational Research 66.4 (1996): 54378. 
OORGANGE EN VOORTGANGE: 'n Huldigingsbundel vir C. H. F. Ohlhoff

Perry, Nancy E., John C. Turner en Debra K. Meyer. “Classrooms as context for motivating learning," in Handbook of Educational Psychology. $2^{\text {de }}$ uitg. Reds. Patricia A. Alexander en Philip H. Winne. Mahwah, JJ: Lawrence Erlbaum, 2006. 327-48.

Pianta, Robert C. Enhancing Relationships between Children and Teachers. Washington DC: American Psychological Association, 1999.

Pomerantz, Eva M., Wendy S. Grolnick, en C.E. Price. "The role of parents in how children approach achievement." Handbook of Competence and Motivation. Reds. Andrew, J. Elliot en Carol, S. Dweck. Nueva York: Guilford Press, 2005. 259-78.

Rodrigues, Richard. Hunger of Memory: The Education of Richard Rodriguez. New York, NJ: Bantam, 1982.

Ryan, Richard M., en Edward L. Deci. "Intrinsic and extrinsic motivations: classic definitions and new directions." Contemporary Educational Psychology 25 (2000): 56-67.

, en Jerome D. Stiller. "The social contexts of internalization: Parent and teacher influences on autonomy, motivation and learning." Advances in Motivation and Achievement Vol 7. Goals and Self-regulatory Processes. reds. Paul R. Pintrich en Martin L. Maehr. Greenwich, CT: JAI, 1991. $115-49$.

, Jerome D. Stiller, en John H. Lynch. "Representation of relationships to teachers, parents and friends as predictors of academic motivation and self-esteem." Journal of Early Adolescence 14.2 (1994): $226-49$.

Schunk, Dale H. "Self-efficacy and academic motivation." Educational Psychologist 26 (1991): 207-31.

Soliday, Michael. "Translating self and difference through literacy narratives." College English 56.5 (1994): 511-26.

Stefanou, Candice R., Kathleen C. Perencevich, Marcello DiCintio, en Julianne C. Turner. "Supporting autonomy in the classroom: Ways teachers encourage student decision making and ownership." Educational Psychologist 39 (2004): 97-110.

Stein, Pippa, en Denise Newfield. "Multiliteracies and multimodality in English education in Africa: mapping the terrain." English Studies in Africa 49.1 (2006): 1-21.

Terenzini, Patrick, Laura T. Rendon, M. Lee Upcraft, Susan Millar, Kevin W. Allison, Patricia L. Gregg en Romero Jalamo. "The transition to college: diverse students, diverse stories." Research in Higher Education 35.1 (1994): 57-73.

Turner, Joan. Language in the Academy: Cultural Reflexivity and Intercultural Dynamics. Bristol, UK Multilingual Matters, 2011.

Urdan, Timothy \& Julianne C. Turner. "Competence motivation in the classroom." Reds. Andrew J. Elliot \& Carol S. Dweck. Handbook of Competence and Motivation. Nueva York: Guilford Press, 2005. 297-317.

Villanueva. Victor. Bootstraps. From an American Academic of Color. Urbana, Illinois: National Council of Teachers of English, 1993.

Wentzel, Kathryn R. "Social goals and social relationships as motivators of school adjustment." Social Motivation: Understanding Children's School Adjustment. Reds. Jaana Juvonen en Kathryn R. Wentzel. Cambridge: CUP, 1996. 226-47.

. "Peer relationships, motivation, and academic performance at school." Reds. Andrew J. Elliot \& Carol S. Dweck. Handbook of Competence and Motivation. Nueva York: Guilford Press, 2005. 279-96.

Williams, Bronwyn T. "Heroes, rebels, and victims: Student identities in literacy narratives" Journal of Adolescent and Adult Literacy 47. 4 (2003): 342-45.

Wroots, Rachel. G. "What can the literacy narrative accounts of EAL students tell us about their transition from high school to university-based academic practices?" MEd thesis, U Cape Town, 2002.

Zammit, Katina P. "Connecting multiliteracies and engagement of students from low SES backgrounds: using Bernstein's pedagogic discourse as a bridge," Language and Education 25.3 (2011): 203-20 